\title{
Eretmochelys imbricata: Lessons to Learn from a Monitoring Program in the North of Mozambique
}

\author{
Rita Anastácio ${ }^{*}$, Cardoso Lopes², Jorge Ferrão ${ }^{2,3}$, Mário Jorge Pereiraa ${ }^{1,4}$ \\ ${ }^{1}$ Departamento de Biologia e CESAM, Universidade de Aveiro, Aveiro, Portugal \\ ${ }^{2}$ Maluane-Cabo Delgado Conservation and Tourism, Pemba, Mozambique \\ ${ }^{3}$ Universidade Pedagógica, Maputo, Mozambique \\ ${ }^{4}$ AFPR - A For Plankton Research, Aveiro, Portugal \\ Email:*a20029@ua.pt
}

How to cite this paper: Anastácio, $\mathrm{R}$, Lopes, C., Ferrão, J. and Pereira, M.J. (2017) Eretmochelys imbricata: Lessons to Learn from a Monitoring Program in the North of Mozambique. Natural Resources, 8, 382396.

https://doi.org/10.4236/nr.2017.85024

Received: April 18, 2017

Accepted: May 23, 2017

Published: May 27, 2017

Copyright (c) 2017 by authors and Scientific Research Publishing Inc. This work is licensed under the Creative Commons Attribution International License (CC BY 4.0).

http://creativecommons.org/licenses/by/4.0/

\begin{abstract}
Monitoring programs for nesting turtles around the world have been important to build up a matrix of information for better comprehension of their behaviour and dispersion. The Western Indian Ocean has several monitoring programs that are being used to reveal migration routes, phylogenetic interconnections and nesting behaviour patterns. We determined the nesting parameters for 69 records of hawksbill turtles collected during the Vamizi Island monitoring program. We also determined carapace measurements parameters of the turtles caught by fishermen in the area and give some considerations to improve the conservation of this species. Results show that the island receives hawksbill females all year long. Vamizi is a small nesting ground for this species, with an incubation period of $60.9 \pm 10.6$ days and a high reproductive rate. The turtles' carapace measurements (SCL $42.0 \pm$ SD $9.0 \mathrm{~cm}$ ) revealed the existence of young individuals, foraging near the island, and their vulnerability to the fishing practices. This study strongly defends the need to identify more developmental and nesting spots, to be protected near Vamizi, to establish a solid network of marine reserves and corridors in the north of the Mozambique Channel.
\end{abstract}

\section{Keywords}

Eretmochelys imbricata, Nesting Parameters, Mozambique Channel (MZC), Network of Marine Reserves

\section{Introduction}

Marine turtles have been of concern of several biologists and conservationists. 
There are some regions in the world where marine turtles survival continues to be challenged by threats that may lead to their extinction [1]. The hawksbill turtle, Eretmochelys imbricata, is listed as critically endangered by the International Union for Conservation of Nature (IUCN) since 1996. In the latest IUCN assessment in 2008, threats like "over-exploitation of adult females and eggs at nesting beaches, degradation of nesting habitats, take of juveniles and adults in foraging areas, incidental mortality relating to marine fisheries, and degradation of marine habitats" are pointed out as the prime causes of "the extensive subpopulation declines in all major ocean basins over the last three hawksbill generations" [2].

Considered as spongivorous turtles, the hawksbill are viewed as healthy habitat keepers, especially in coral reef ecosystems [3]. However in the Indo-Pacific Oceans (review by Bjorndal [4]) they tend to have an omnivorous diet regime [2], having the roles of habitat health keepers and of top consumers. Hawksbill females nest in sandy beaches under vegetation during the night, but sometimes during the day [2]. This nesting behaviour can be conditioned by anthropogenic disturbances, like human presence, beach-front development and clearing of dune vegetation [2]. Like other marine turtles, this species shows a seasonal pattern for nesting activity. In certain locations like Tanzania, their nesting activity is more regular and shows a nesting peak [5]. In other Western Indian Ocean (WIO) locations hawksbill nesting appearances are sporadic and irregular [6], possibly as a response to abiotic factors variations. Long term data are scarce for several African eastern countries [7] [8], and this is the reason why Vamizi's marine turtles monitoring program is important. The Vamizi program generated two papers for green turtles [7] [9] providing information for this part of the Mozambique coast. Other studies conducted in the island bring some insight on the fishery pressures [10] affecting marine turtles. Obura et al. [8] emphasizes the increase of the fishing pressures in the WIO, due to the amplification of the local populations. Also, the extraction of oil and gas in Kenya, Tanzania, Mozambique, Madagascar and Seychelles (some from very recent discoveries) is increasing [8]. This will probably lead to a migration of people to these areas in search of better conditions of life, and to an increase in pressures on natural resources and ecosystems. Migrant fishermen are already pointed by Mozambican fishermen as the main cause of resources degradation [11].

The main objective of this study is to reveal aspects of the monitoring program of the Vamizi Island concerning the hawksbill turtles, i.e. the nesting parameters on monitored beaches. It is intended to understand which threats and pressures are felt in the region, and what needs to be accomplished to improve the conservation of this species locally and in other WIO locations. This way, we intend to contribute with more information about hawksbill nesting turtles in the north of Mozambique, an effort requested by several publications for parts of the world from where data is scarce [12] [13] [14] [15] [16]. This information can be helpful in providing justified insight to extend the Vamizi's protected area boundaries, or in answering questions seen as global research priorities for marine turtles [16] or, even, in determining a conservation unit for this part of the Indian Ocean. 


\section{Methods}

\subsection{Study Area}

The Vamizi Island is one of the many islands of the East African Coast. It is located in the north of Mozambique [9] (latitude between $11^{\circ} 00^{\prime} \mathrm{S}-11^{\circ} 10^{\prime} \mathrm{S}$; longitude between $40^{\circ} 30^{\prime} \mathrm{E}-40^{\circ} 50^{\prime} \mathrm{E}$ ), belonging to the Quirimbas Archipelago (Figure 1) and to the $95^{\text {th }}$ WIO Ecoregion, following the 2007 Marine Ecoregions of the World (MEOW) classification scheme [8]. Vamizi Island (Figure 2) has approximately $48 \mathrm{~km}^{2}[10]$ and its beaches are composed of biogenic sand and some, especially in Comissete and Farol beaches, are used as rookeries by green [7] [9] and hawksbill turtles [7]. The west and south sides of the island are occupied by local poor people that live mainly from fishing practices. But this area is also explored by foreign fishermen, especially from Tanzania, who catch marine turtles for meat consumption [8]. This habitat is known to support populations of nesting and maturing hawksbill turtles, as emphasized by Garnier et al. [7].

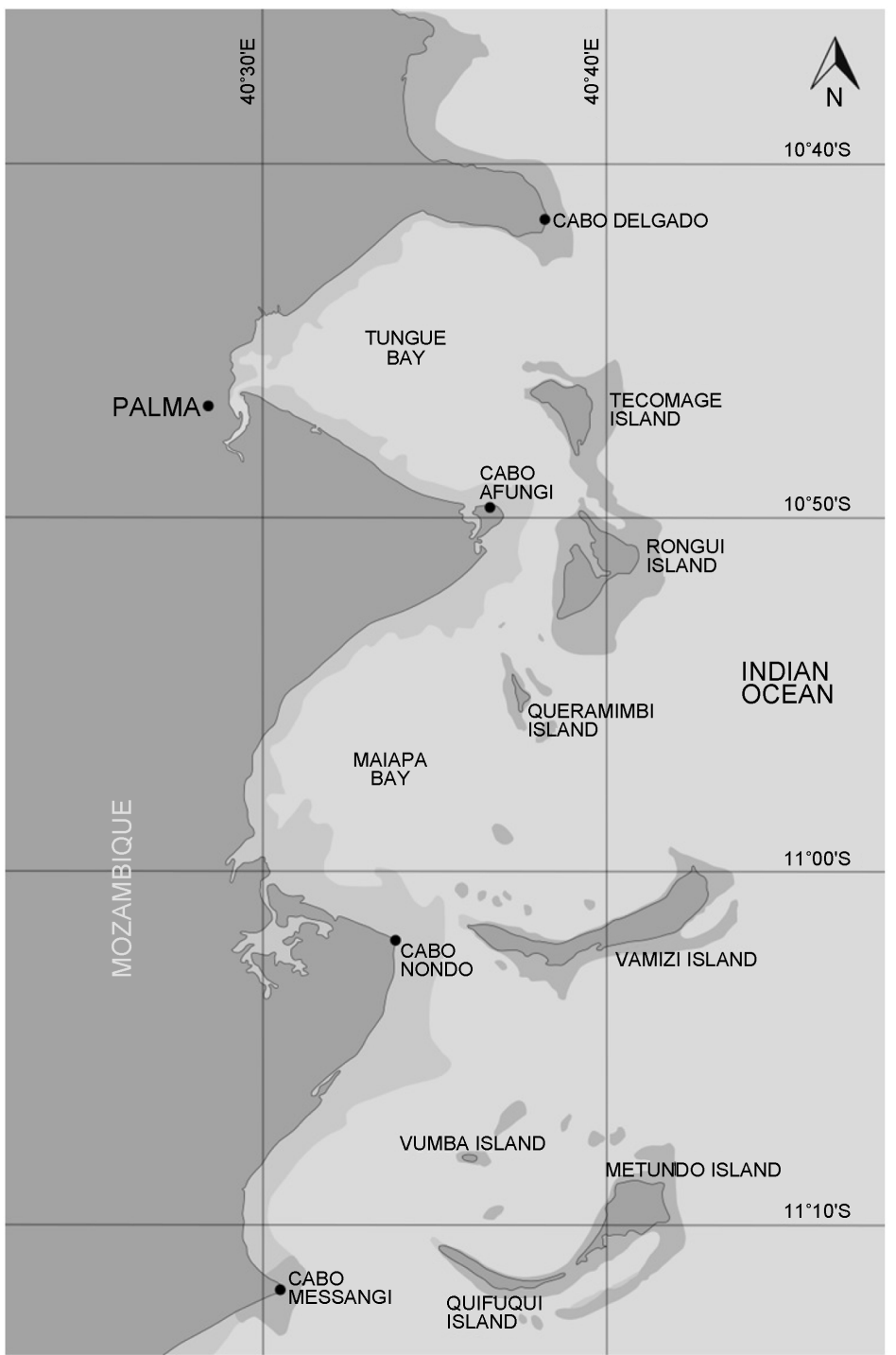

Figure 1. Map of the studied area. 
Air temperature amplitude in Vamizi is low but precipitation varies considerably [9]. Between 2004 and 2010 precipitation averages were below $50 \mathrm{~mm}$ and 2005 was a particularly dry year [9]. This climate pattern is due to the MZC features since it is a very energetic zone; in the north of the channel, the Comoros gyre and the eddies sustain fertile food webs, with endemic species probably due to the efficient east-west exchange of water contents, enhanced by the many islands inside the channel [8]. Also, MZC water speed and variability is strongly modulated by the monsoons seasonality, but also by the Indian Dipole which interferes with the sea surface temperatures, hence with the rainfall [8].

\subsection{Monitoring Program and Data Collection}

The monitoring program started in September 2002 with foot patrols, conducted daily by a team of prepared monitors (at least three people), who gathered information on paper forms [9] [17]. Comissette and Farol beaches were more intensively monitored in day patrols from October 2003 on. Night patrols were conducted every night during the nesting activity peak, from 2004 to 2010 (Table 1).

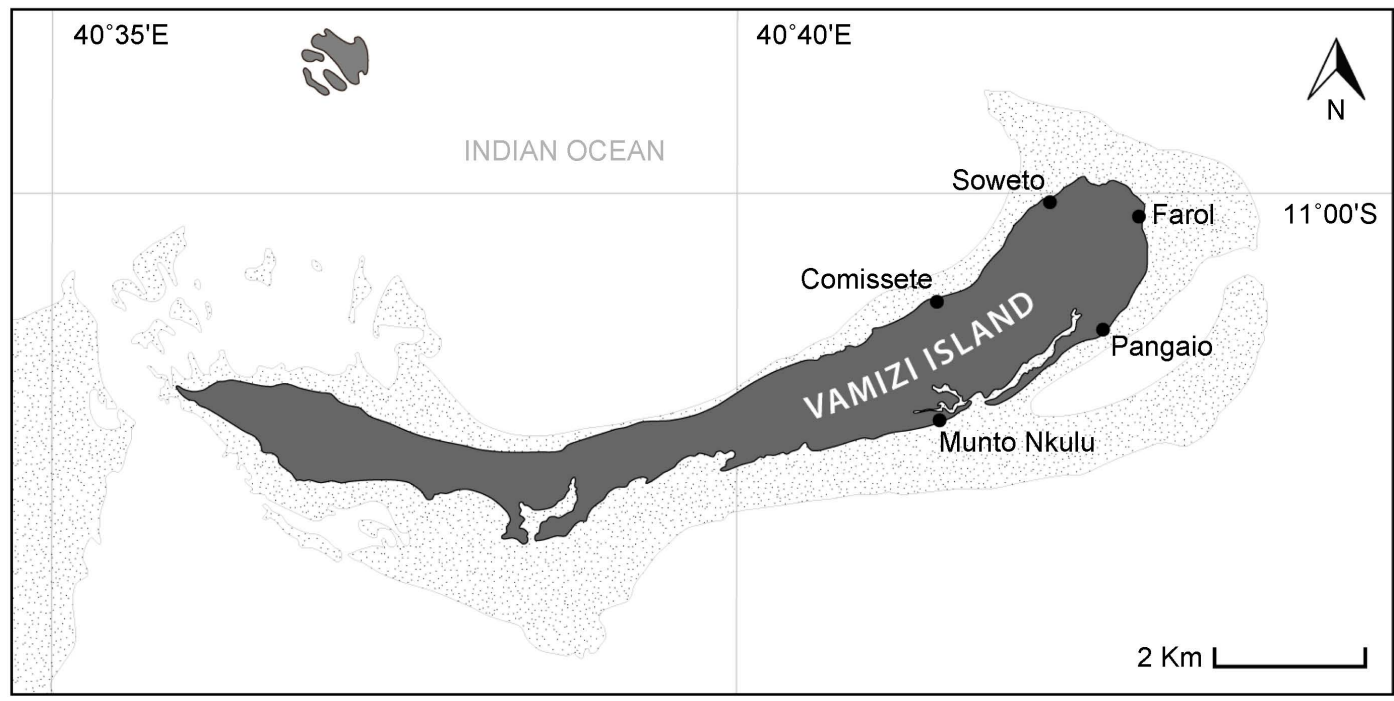

Figure 2. Vamizi Island in detail and location of the monitored beaches.

Table 1. Field effort period (grey areas), per year, of the night-time patrols.

\begin{tabular}{|c|c|c|c|c|c|c|c|c|c|c|c|c|}
\hline \multirow[b]{2}{*}{ Year } & \multicolumn{12}{|c|}{ Month } \\
\hline & 1 & 2 & 3 & 4 & 5 & 6 & 7 & 8 & 9 & 10 & 11 & 12 \\
\hline 2004 & & & & & & & & & & & & \\
\hline 2005 & & & & & & & & & & & & \\
\hline 2006 & & & & & & & & & & & & \\
\hline 2007 & & & & & & & & & & & & \\
\hline 2008 & & & & & & & & & & & & \\
\hline 2009 & & & & & & & & & & & & \\
\hline 2010 & & & & & & & & & & & & \\
\hline
\end{tabular}


The day patrol monitors had the responsibility for, every morning check turtle activity above the high tide line, such as tracks and nesting marks (differentiating between nesting and non-nesting emergences). Hawksbill turtle's identification (ID) was made following Pritchard and Mortimer description in Eckert et al. [17]; but the thick overlapping (imbricate) scutes of the carapace and the straight bird-like beak of the head are two characteristics of this species.

New nests were identified and marked (with bamboo poles behind the nest) and their global positioning system coordinates (GPS) were taken. In addition to the information of the nesting date, the information of the hatching activity was taken to evaluate hatching success (e.g. hatching date, excavation date, number of hatched individuals at the nest and/or undeveloped, not before 90 days after eggs laid, among other parameters). Following Schroeder and Murphy [18] a crawl was interpreted as "tracks and other sign left on a beach by a sea turtle"; and a "False Crawl" was interpreted as "a crawl resulting from an abandoned nesting attempt (a non-nesting emergence)". The teams identified marine turtle species using tracks, or, when captured, using morphometry of the individuals (nesting females at the beaches and other individuals brought by fishermen).

The identification of the turtles [19] and their biometric information was given by their minimum curved carapace length, or CCL, and curved carapace width, CCW, lengths following Bolten's [20] methodology, and by the size and shape of the tracks [18] [19]. Each measure was taken three times and recorded. The CCL measures were converted to straight carapace lengths (SCL) following the equation in Teas [21]. Local fishermen were given incentive to bring turtles accidentally captured on fishing techniques. These turtles were also measured for CCL and CCW lengths.

Tagging procedures were made according to Balazs [22]. Titanium tags (www.stockbrands.com.au/titanium.html) (Stockbrands Pty Ltd., Perth, Australia, www.stockbrands.com.au) were used and applied in both proximal front flippers. The first external tags were applied on 18th March 2004 (MZC 0004/ MZC 0005; turtle ID VZ001). The examination for tags in the nesting females occurred during night patrols, but this was also made with the turtles brought by the fishermen. The presence of tags (tag series from MZC 0000 to MZC 0999) was recorded, and missing tags were replaced. For all observed/captured turtles, date, site, tag number and activity was recorded. The individual's location coordinates were taken with a GPS device, Magellan NAV5000D, used in 2D non-differential mode.

\subsection{Data Analysis}

For the determination of nesting parameters we used samples from Comissete, Farol, Pangaio, Munto Nkulu and Soweto beaches (Figure 2). Nesting parameters averages were obtained using records of all beaches combined and per beach. The nesting success was estimated "as the proportion of nesting activities that resulted in a nest" [23]. The clutch size, hatching and emergence successes were determined following the methodology described by Miller [24] using the 
records of all beaches. The number of eggs laid per year, the average of nests per year, and the average of nests per month were also determined. The hatching success was defined as "the proportion of hatchlings that hatched out of their shells respectively" [24]. Emergence success was defined "as the proportion of hatchlings that reached the beach surface" [24]. The formulas used to determine the clutch size, hatching and emergence successes were the ones described by Miller [24].

The incubation period was obtained using all records from all the sampled beaches, and according to the date when the nest was laid.

Our sample included $\mathrm{N}=69$ records collected in beaches (concerning nesting activity), and $\mathrm{N}=103$ records of marine turtles captured by fishermen. These records concern data collected between 2002 and 2010. All the statistical analysis was performed on PASW Statistics 18 and on Microsoft Office Excel 2007 software. The significance was estimated at the $95 \%$ confidence level. Variables like incubation period, clutch size, hatching and emergence successes were compared for the two main beaches using a t-test (samples with $\mathrm{N}<50$ ), for which we tested variance homogeneity using the Levene's Test $(\mathrm{P}<0.05)$.

\section{Results}

\subsection{Turtles Bycatch}

A total of 103 hawksbill turtles were captured by hand or caught accidently in nets or by other fishing techniques. The captures were reported between May of 2004 and February of 2009. Of those turtles, 79.6\% were captured by nets in several places from Mocimboa da Praia to Palma, near Vamizi Island beaches, or in other places located at north ("Baixo" Mepanga-Panga), or at south (Vumba, Metundo, Quissanga) of the island (Figure 1).

\subsection{Turtles Carapace Measurements and Tagging}

The total number of tagged hawksbill turtles was $\mathrm{N}=111$, being the majority of the measured the ones that were captured, i.e. 103 turtles, all of them tagged. The analysis of the records shows that $79.6 \%$ of the turtles were captured in nets, 46 of them identified as "jarifas".

The CCL average of the hawksbill turtles measured (2004-2009) was $44.2 \pm 9.4$ $\mathrm{cm}(\mathrm{N}=111)$ ranging from 30 to $88 \mathrm{~cm}$ (Figure 3), and the CCW average was $39.6 \pm 8.1 \mathrm{~cm}(\mathrm{~N}=111)$ ranging from 27 to $78 \mathrm{~cm}$.

The turtles captured and measured in 2004, 2007 and 2008 were smaller than the turtles measured in 2005 and 2009. However, 2009 shows a great dispersion of the CCL values, indicating the existence of small turtles in that year. The SCL estimated for our sample is $42.0 \pm 9.0 \mathrm{~cm}$. The SCL estimated for the sample of turtles brought by fishermen is smaller, $41.7 \pm 8.5 \mathrm{~cm}$.

\subsection{Reproductive Biology, Nesting Parameters}

The number of records for hawksbill nesting turtles, taken on Vamizi beaches, is shown in percentage in Figure $4(\mathrm{~N}=69)$. 

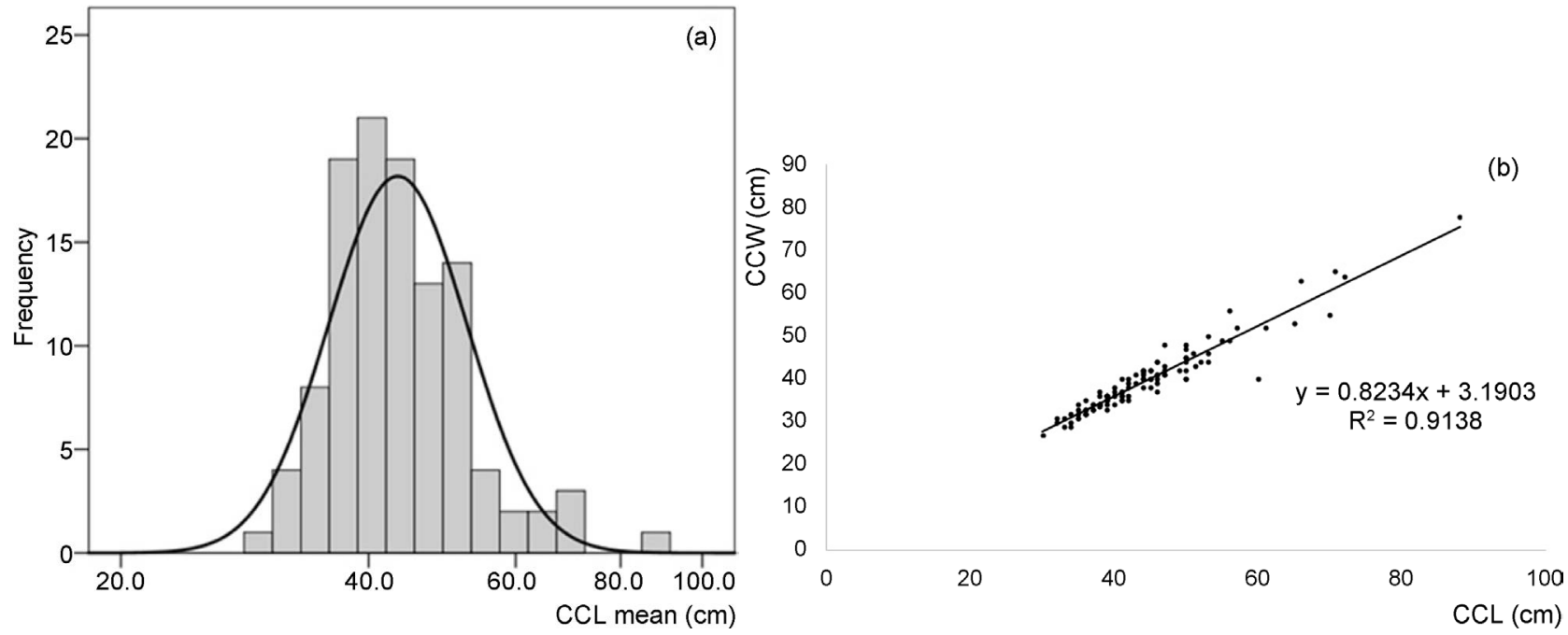

Figure 3. (a) Distribution (logarithmic scale) of the CCL sample $(\mathrm{N}=111)$. (b) Correlation graph between CCL and CCW measurements for the hawksbill turtles of the Vamizi project; the equation $y=0.8234 x+3.1903$ shows the correlation between CCL and CCW lengths of the measured turtles. The $\mathrm{R}^{2}$ value $(0.9138)$ shows a strong correlation between the two variables, as expected.
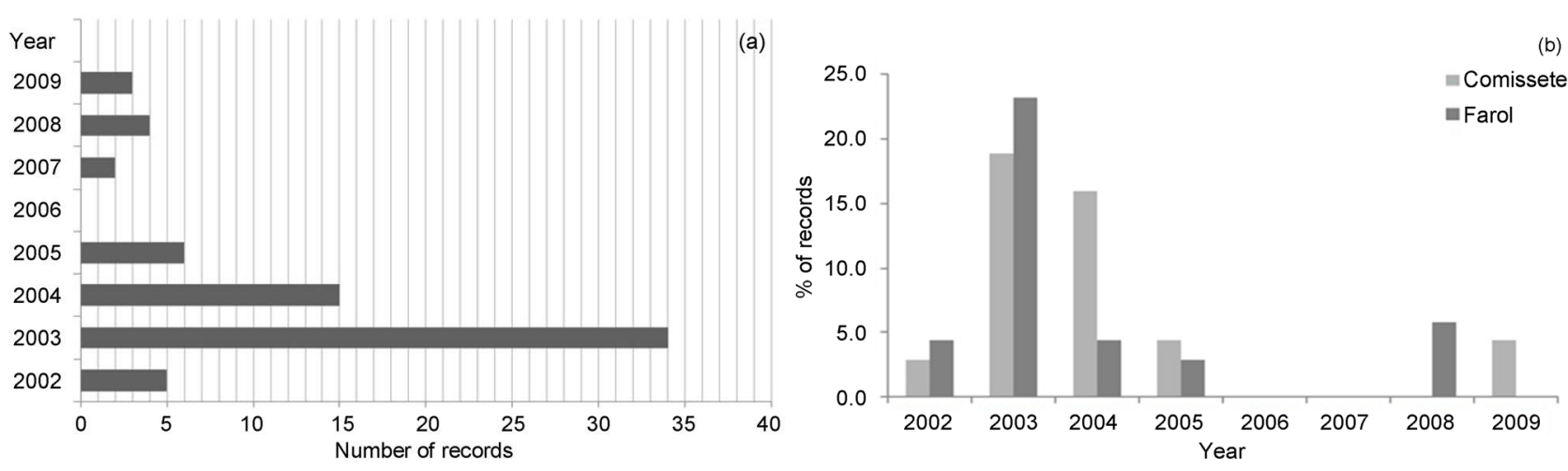

Figure 4. (a) Total number of emergences in Vamizi beaches/year. (b) Comparison of number of records of nesting females in Comissete and Farol beaches per year.

The majority of the nesting activity was recorded in 2003 (34 emergences) and 2004 (15 emergences). There is no data on hawksbill turtles for 2006 and 2010, though there is data in the same conservation program for green turtles. This indicates low numbers of individuals for the hawksbill population for some years and, especially, from 2005 forward.

Recorded nesting activity $(\mathrm{N}=69)$ was, per beach, in percentage, the following: Comissete (46.4), Farol (40.6), Munto Nkulo (8.7), Pangaio (4.3).

The overall nesting success was $73.9 \%$; in average, 4 nests.month ${ }^{-1}$ (all sampled beaches combined) were laid, being the highest nesting activity observed in December and January. Comissete beach showed the highest value of nests/month in December-January and Farol beach in July-August.

The average clutch size (all beaches combined, for 2002-2005, 2008, 2009 years), was $128.0 \pm 30.0$ eggs $(\mathrm{N}=28)$. The Comissete beach has an average clutch size of $133.6 \pm 31.9$ eggs $(\mathrm{N}=16)$, and Farol beach has an average clutch size of $124.1 \pm 25.1$ eggs $(\mathrm{N}=11)$. 
The overall mean hatching success was $86.5 \% \pm 18.9 \%(\mathrm{~N}=28)$. For Comissete beach the hatching success was $89.2 \pm 11.4(\mathrm{~N}=16)$, whereas for Farol beach was $81.4 \pm 26.9,(\mathrm{~N}=11)$. The overall mean emergence success was $81.6 \% \pm 23.5 \%$ $(\mathrm{N}=28)$ (for Comissete: $83.7 \pm 18.4, \mathrm{~N}=16$; for Farol: $77.0 \pm 30.5, \mathrm{~N}=11$ ).

The incubation period (i.p.), considering all observed beaches was $60.9 \pm 10.6$ days $(\mathrm{N}=35)(2002-2005,2008,2009)$. The overall averages of i.p. in Vamizi beaches are as follows: North facing beachs - Comissete $56.9 \pm 4.5$ days $(\mathrm{N}=16)$; South facing beaches - Farol beach, $62.7 \pm 7.6$ days $(\mathrm{N}=15)$; Munto Nkulo beach, $70.3 \pm 25.9$ days $(\mathrm{N}=4)$. Table 2 summarizes carapace measurements and nesting parameters averages for Vamizi hawksbill turtles.

The t-tests performed to compare means of clutch size, hatching success, emergence success and i.p. between Comissete and Farol, indicated that there are no significant differences between these two beaches for clutch size $(t=0.83<$ 1.96, for 25 degrees of freedom, i.e. d.f.; variances homogeneity assumed with $\mathrm{P}=$ $0.66>0.05)$, and hatching success $(t=1.04<1.96$, for 25 d.f.; variances homogeneity assumed with $\mathrm{P}=0.22>0.05)$. For the emergence successes of Comissete and Farol samples there is no variance homogeneity $(\mathrm{P}=0.04<0.05 ; \mathrm{t}=0.65<$ 1.96, for 15 d.f.). And, there is a significant difference for the i.p. on these two beaches (the Levene's Test indicates homogeneous variances, $\mathrm{P}=0.164>0.05$, for 29 d.f.; and $t=2.624,29$ d.f., $>1.96$ showing significant difference between i.p. from Comissete when compared with the i.p. from Farol).

\section{Discussion}

\subsection{Turtles Bycatch}

Hawksbill turtles are being captured by fishing gear, especially by nets in the Vamizi area. Being omnivorous it is likely that these turtles are attracted by small prays functioning as turtle baits. Hence, the nets function as hawksbill traps. This is a problem already indicated by Bourjea et al. [25] for the WIO.

Table 2. Summary of carapace measurements and nesting parameters results.

\begin{tabular}{|c|c|c|c|}
\hline & Average & Range & $\mathbf{N}$ \\
\hline \multicolumn{4}{|l|}{ Carapace Measurements } \\
\hline CCL & $44.2 \pm 9.4 \mathrm{~cm}$ & $30-88 \mathrm{~cm}$ & 111 \\
\hline CCW & $39.6 \pm 8.1 \mathrm{~cm}$ & $27-78 \mathrm{~cm}$ & 111 \\
\hline SCL & $42.0 \pm 9.0 \mathrm{~cm}$ & & 111 \\
\hline SCL bycatch turtles & $41.7 \pm 8.5 \mathrm{~cm}$ & & 103 \\
\hline \multicolumn{4}{|l|}{ Nesting Parameters } \\
\hline Peak of nesting season & December-January & & \\
\hline Frequency of nests & 4 nests/month & & \\
\hline Clutch size & $128.0 \pm 30.0$ eggs & 98 - 158 eggs & 28 \\
\hline Hatching Success & $86.5 \% \pm 18.9 \%$ & & 28 \\
\hline Emergence Success & $81.6 \% \pm 23.5 \%$ & & 28 \\
\hline Incubation Period & $60.9 \pm 10.6$ days & 50 - 72 days & 35 \\
\hline
\end{tabular}


There is a need to clear the area of possible abandoned fishing gear, as an important conservation strategy. This could be done by local fishermen, with some monetary incentive.

Rosendo et al. [11], in a field-based research in the north of Mozambique (at Quirinde, Palma, Mocimboa da Praia and Ulo), analyzed local fishermen opinions about marine resources, who said that a "growing number of migrant fishers" from Nampula Province (Mozambique) and Tanzania, "that use harmful fishing gear", like nets with very small-sized meshes ("cavogo" and "jarifa"), explosives, poisons and scuba equipment, and "the lack of law enforcement" were the main causes for the difficulties lived by locals. Rosendo et al. [11] found that these migrant fishermen tend to explore marine resources in the north of Mozambique more intensively than the local fishermen. Our results show that 46 of the captures were due to "jarifas", a 6-inch mesh net identified in Tanzania as a "major threat to sea turtles" [25], hence corroborating Rosendo's findings.

\subsection{Turtles Carapace Measurements}

An aspect revealed by this study is the small dimensions of the turtles measured. Twenty six juveniles sampled in Ascension Island [26] had an average of $47 \mathrm{~cm}$ CCL (range: $35-60 \mathrm{~cm}$ ). This means that the measured average of the Vamizi's hawksbill turtles were most certainly juveniles. The estimated SCL average of the hawksbill turtles tagged in Vamizi shows that they had, possibly, between 4 to 6 years, following growth curves [27]. It appears that the near-shore benthic habitats between the Tungue Bay and Metundo Island (Figure 1) are used as developmental habitats by the juvenile Mozambican hawksbill turtles. But, could this mean that the hawksbill turtles in the WIO are smaller than other locations? Or that they mature more rapidly? We cannot answer yet these questions, since there is the need to collect more data, but they certainly need to be answered.

\subsection{Reproductive Biology}

Although there are records from all year long on the Vamizi program, the nesting peak occurs between December and January, which is similar to results from a study in Mafia Island, Tanzania [5]. The nesting season occurs between September and April, which is consistent with data from the Republic of Seychelles [28], with an exception to Farol beach, where July and August are also included in the nesting season.

The average value for the Vamizi clutch size is smaller (128.0 \pm 30.0 eggs, ranging between 98 - 158 eggs) when compared with the clutch size (110 - 180 eggs/nest) settled for this species [17]. In a Seychelles study a mean clutch size of 178.7 eggs was determined for 6 hawksbill nesting females [29]. At Mafia Island the clutch size is also higher ( $143 \pm 24$ eggs $)$ when compared with Vamizi's results. The results reflect smaller clutches indicating, possibly, smaller or younger females (see reference [30]). However, we are inclined to think that nesting hawksbill females were young breeders, with capacity to carry fewer eggs. And this raises other questions: where are the mature turtles? Are they being captured 
before they have the chance to reach the nesting beaches? Are these results indicating that hawksbill turtles are in decline in Mozambican waters? Are bigger turtles in their migration routes? Despite the small clutches, the overall hatching success rate $(86.5 \% \pm 18.9 \%)$ is higher than the $73 \% \pm 25 \%$ estimated for hawksbill turtles of Mafia Island [5]. This may be due to the sand quality parameters since identical results were obtained for the green marine turtles in the same conservation program (see reference [9]), meaning that Vamizi is one of the places on Earth with the highest estimate for reproductive rates [31]. This result sustains the importance of Vamizi's beaches to incubate hawksbill eggs, but also, the need to ensure a safe route towards the island.

The incubation period is smaller in Comissete than in the eastern or southern beaches of the island. In fact, there is a statistical significant difference between the incubation period of Comissete compared with the incubation period of Farol. This was already expected, since the same pattern was found for green turtle clutches during the same period of time [9], and indicates a similar pattern for the incubation of eggs of these two species, affected in the same way by the abiotic factors of these two beaches. North facing beaches like Comissete are exposed to higher solar radiation that will heat more the surface of the sand [32]. This will certainly provide warmer incubating environments than in beaches with other orientations, like Farol or Muntu Nkulo. Other aspect shown by Comissete is that since its incubation period is smaller in average, because its sands are warmer, it is most likely that each Comissete nest produces more females, than males [33]. But this is only speculation, since there is no information on nest's shade percentage, or a strategy taken to determine nest temperatures (for example, by placing temperature data loggers inside a sample of nests).

\subsection{Conservation}

The Vamizi Island, though confirmed as a nesting spot for green and hawksbill turtles in the region, is so small that one may consider it to be inefficient in preserving marine turtles. However, even small nesting beaches may be important to recover sea turtles populations. For example, during the project, 57 samples of DNA tissue from hawksbills were collected and analysed. The genetic analysis (mitochondrial DNA control region sequencing of $>845 \mathrm{bp}$ ) showed 14 haplotypes for the Vamizi's turtles, 12 of which identified (2011) as new haplotypes (isolates 49, 60, 65, 73, 95, 97, 101, 102, 104, 113, 114 and 128 GenBank, JF926554.1, JF926544.1， JF926553.1， JF926547.1， JF926546.1， JF926545.1， JF926548.1, JF926549.1, JF926550.1, JF926555.1, JF926551.1 and JF926552.1 respectively) [34]. This indicates that Vamizi has high haplotype diversity. Is this an expanding population? Is this a new management unit (MU) or can it be included in a Regional Management Unit (the Indian Southwest RMU, see [12]) that also considers Seychelles turtles, for example? To address these questions more research and a better protection of the habitats are needed.

The captures reported in this study reveal that the conservation area must be extended to other islands but, especially, to the habitats used by smaller turtles. 
Moreover, two major threats were identified on Vamizi Island and its proximity: bycatch of turtles in fishing activities (by local and migrant fishermen); and disturbance of the nesting habitats due to anthropogenic presence.

To mitigate the bycatch problem in a short-time period, it is proposed the strategies used by Wang et al. [35]: shark shapes placed along the length of the gill nets, illumination of nets by LED lights, and nets illuminated with chemical light sticks. Perhaps the use of deterrents similar to those described by Wang et al. [35] may be tested by local fishermen (e.g., Kivuri fishermen were proactive in this study). It would be important to give incentive to local populations, for simple but important measures like searching and clearing the area of abandoned fishing gear. More supervision of fishing activities by local authorities would be essential.

The disturbance of nesting habitats by people may be other important cause for the reduction of nesting females on Vamizi beaches, since hawksbills are particularly sensitive to the presence of people [2]. Farol and Comissete beaches are two important nesting grounds for green turtles (with higher nesting activity when compared to hawksbill) and have been explored economically, though with conservation efforts and compromises. The results show a coincidence in the decline of nesting female emergence records in these two beaches for green [9] and hawksbill turtles. This is a sign that the conservation measures applied are not being effective. The low number of emergences of hawksbill females at Vamizi beaches may be due, as well, to increased mortality of turtles as bycatch in the migrating routes, between other feeding grounds and Vamizi surroundings (this is speculative, since it is poorly documented). The existence of a considerable number of small turtles in the area and the threats identified, plus the existence of nesting females, indicates that the habitats near Vamizi must be effectively protected urgently. In what regards this matter, the strategy of mapping a connection between patches of significant habitats (for feeding, development, nesting and, perhaps mating) used by the WIO hawksbill turtles is largely defended by our team. These patches, and corridors of connection between them, could help to define a network of marine reserves in the north of the MZC. The idea of a network of marine protected areas (MPAs) and corridors connecting them is defended by Gaines et al. [36], because it is not possible to have reserves large enough for highly migratory and long living species that explore different habitats over their life time. Also, these authors defend the idea of redundancy (or, as they call it "replication"), i.e. "placement of multiple reserves in each habitat" [36]. Though more research is needed, the area is already seen as a site with Outstanding Universal Value (OUV) [8], hence it needs to be protected.

We believe it could be possible to ensure the preservation of this sub-adult foraging and nesting habitat, since the gas industry already established in the area (at Tungue Bay) is providing the conditions to sustain an informal marine reserve. It retains and mitigates the exploitation of marine resources by illegal fishermen in these areas. Efforts between stakeholders (from luxury tourism and gas industries), government, scientists and local populations are essential to 
achieve a sustainable development for these habitats, and a preservation of the corals, which are so important to hawksbill marine turtles.

\section{Acknowledgements}

We are grateful to Doctor Julie Garnier for her management of the program, including the study design and coordination (the field work and data collection), and to Rachid Abudala (Major Dade) who was responsible for the logistic support. Also, we thank to all personnel involved in the field work. The authors are grateful to the Maluane Conservation Project (Cabo Delgado Tourism, Biodiversity and Conservation), that started this work, that continues till our days. We are especially grateful to the private donors, who have contributed for the Maluane Conservation Community and the Development Program (1998) and for the "Turtles monitoring programme" (2002).

\section{References}

[1] Broderick, A.C., Frauenstein, R., Glen, F., Hays, G.C., Jackson, A.L., Pelembe, T., Ruxton, G.D. and Godley, B.J. (2006) Are Green Turtles Globally Endangered? Global Ecology and Biogeography, 15, 21-26. https://doi.org/10.1111/j.1466-822X.2006.00195.x

[2] Mortimer, J.A. and Donnelly, M. (IUCN SSC Marine Turtle Specialist Group) (2008) Eretmochelys imbricata. The IUCN Red List of Threatened Species. Version 2014.2. www.iucnredlist.org

[3] Hawkes, L.A., Broderick, A.C., Godfrey, M.H. and Godley, B.J. (2009) Climate Change and Marine Turtles. Endangered Species Research, 7, 137-154. https://doi.org/10.3354/esr00198

[4] Bjorndal, K.A. (1997) Foraging Ecology and Nutrition of Sea Turtles. In: Lutz, P.L. and Musick J.A., Eds., The Biology of Sea Turtles, CRC Press, Boca Raton, FL, 199231.

[5] West, L. (2010) A Multi-Stakeholder Approach to the Challenges of Turtle Conservation in the United Republic of Tanzania. Indian Ocean Turtle Newsletter, 11, 4450 .

[6] Lauret-Stepler, M., Ciccione, S. and Bourjea, J. (2010) Monitoring of Marine Turtles Reproductive Activities in Juan de Nova, Eparses Islands, South Western Indian Ocean, Based on Tracks Count and Width. Indian Ocean Turtle Newsletter, 11, 18 23.

[7] Garnier, J., Hill, N., Guissamulo, A., Silva, I., Witt, M. and Godley, B. (2012) Status and Community-Based Conservation of Marine Turtles in the Northern Querimbas Islands (Mozambique). Oryx, 46, 359-367.

https://doi.org/10.1017/S0030605311001566

[8] Obura, D.O., Church, J.E. and Gabrié, C. (2012). Assessing Marine World Heritage from an Ecosystem Perspective: The Western Indian Ocean. World Heritage Centre, United Nations Education, Science and Cultural Organization (UNESCO), 124 p.

[9] Anastácio, R., Santos, C., Lopes, C., Moreira, H., Souto, L., Ferrão, J., Garnier, J. and Pereira, M.J. (2014) Reproductive Biology and Genetic Diversity of the Green Turtle (Chelonia mydas) in Vamizi Island, Mozambique. SpringerPlus, 3, 540. www.springerplus.com/content/3/1/540 https://doi.org/10.1186/2193-1801-3-540 
[10] da Silva, I.M., Hill, N., Shimadzu, H., Soares, A.M.V.M. and Dornelas, M. (2015) Spillover Effects of a Community-Managed Marine Reserve. PLOS ONE, 10, e0111774. https://doi.org/10.1371/journal.pone.0111774

[11] Rosendo, S., Brown, K., Joubert, A., Jiddawi, N. and Mechisso, M. (2011) A Clash of Values and Approaches: A Case Study of Marine Protected Area Planning in Mozambique. Ocean \& Coastal Management, 54, 55-65.

[12] Wallace, B.P., DiMatteo, A.D., Hurley, B.J., Finkbeiner, E.M., Bolten, A.B., Chaloupka, M.Y., Hutchinson, B.J., Abreu-Grobois, F.A., Amorocho, D., Bjorndal, K.A., Bourjea, J., Bowen, B.W., Dueñas, R.B., Casale, P., Choudhury, B.C., Costa, A., Dutton, P.H., Fallabrino, A., Girard, A., Girondot, M., Godfrey, M.H., Hamann, M., López-Mendilaharsu, M., Marcovaldi, M.A., Mortimer, J.A., Musick, J.A., Nel, R., Pilcher, N.J., Seminoff, J.A., Troëng, S., Witherington, B. and Mast, R.B. (2010) Regional Management Units for Marine Turtles: A Novel Framework for Prioritizing Conservation and Research across Multiple Scales. PLoS ONE, 5, e15465. https://doi.org/10.1371/journal.pone.0015465

[13] Hamann, M., Godfrey, M.H., Seminoff, J.A., Arthur, K., Barata, P.C.R., Bjorndal, K.A., Bolten, A.B., Broderick, A.C., Campbell, L.M., Carreras, C., Casale, P., Chaloupka, M., Chan, S.K.F., Coyne, M.S., Crowder, L.B., Diez, C.E., Dutton, P.H., Epperly, S.P., FitzSimmons, N.N., Formia, A., Girondot, M., Hays, G.C., Cheng, I.J., Kaska, Y., Lewison, R., Mortimer, J.A., Nichols, W.J., Reina, R.D., Shanker, K., Spotila, J.R., Tomás, J., Wallace, B.P., Work, T.M., Zbinden, J. and Godley, B.J. (2010) Global Research Priorities for Sea Turtles: Informing Management and Conservation in the 21st Century. Endangered Species Research, 11, 245-269. https://doi.org/10.3354/esr00279

[14] Wallace, B.P., DiMatteo, A.D., Bolten, A.B., Chaloupka, M.Y., Hutchinson, B.J., Abreu-Grobois, F.A., Mortimer, J.A., Seminoff, J.A., Amorocho, D., Bjorndal, K.A., Bourjea, J., Bowen, B.W., Dueñas, R.B., Casale, P., Choudhury, B.C., Costa, A., Dutton, P.H., Fallabrino, A., Finkbeiner, E.M., Girard, A., Girondot, M., Hamann, M., Hurley, B.J., López-Mendilaharsu, M., Marcovaldi, M.A., Musick, J.A., Nel, R., Pilcher, N.J., Troëng, S., Witherington, B. and Mast, R.B. (2011) Global Conservation Priorities for Marine Turtles. PLoS ONE, 6, e24510. https://doi.org/10.1371/journal.pone.0024510

[15] Bagda, E., Bardakci, F. and Turkozan, O. (2012) Lower Genetic Structuring in Mitochondrial DNA than Nuclear DNA among the Nesting Colonies of Green Turtles (Chelonia mydas) in the Mediterranean. Biochemical Systematics and Ecology, 43, 192-199.

[16] Rees, A.F., Alfaro-Shigueto, J., Barata, P.C.R., Bjorndal, K.A., Bolten, A.B., Bourjea, J., Broderick, A.C., Campbell, L.M., Cardona, L., Carreras, C., Casale, P., Ceriani, S.A., Dutton, P.H., Eguchi, T., Formia, A., Fuentes, M.M.P.B., Fuller, W.J., Girondot, M., Godfrey, M.H., Hamann, M., Hart, K.M., Hays, G.C., Hochscheid, S., Kaska, Y., Jensen, M.P., Mangel, J.C., Mortimer, J.A., Naro-Maciel, E., Ng C.K.Y., Nichols, W.J., Phillott, A.D., Reina, R.D., Revuelta, O., Schofield, G., Seminoff, J.A., Shanker, K., Tomás, J., van de Merwe, J.P., Van Houtan, K.S., Vander Zanden, H.B., Wallace, B.P., Wedemeyer-Strombel, K.R., Work, T.M. and Godley, B.J. (2016) Are We Working towards Global Research Priorities for Management and Conservation of Sea Turtles? Endangered Species Research, 31, 337-382. https://doi.org/10.3354/esr00801

[17] Eckert, K.L., Bjorndal, K.A., Abreu-Grobois, F.A. and Donnelly, M., Eds. (1999) Research and Management Techniques for the Conservation of Sea Turtles. No. 4, IUCN/ Species Survival Commission Marine Turtles Specialist Group Publication, Washington DC. 
[18] Schroeder, B. and Murphy, S. (1999) Population Surveys (Ground And Aerial) on Nesting Beaches. In: Eckert, K.L., Bjorndal, K.A., Abreu-Grobois, F.A. and Donnelly, M., Eds., Research and Management Techniques for the Conservation of Sea Turtles, No. 4, IUCN/Species Survival Commission Marine Turtles Specialist Group Publication, Washington DC, 45-55.

[19] Pritchard, P.C.H. and Mortimer, J.A. (1999) Taxonomy, External Morphology and Species Identification. In: Eckert, K.L., Bjorndal, K.A., Abreu-Grobois, F.A. and Donnelly, M., Eds., Research and Management Techniques for the Conservation of Sea Turtles, No. 4, IUCN/Species Survival Commission Marine Turtles Specialist Group Publication, Washington DC, 31-48.

[20] Bolten, A.B. (1999) Techniques for Measuring Sea Turtles. In: Eckert, K.L., Bjorndal, K.A., Abreu-Grobois, F.A. and Donnelly, M., Eds., Research and Management Techniques for the Conservation of Sea Turtles, IUCN/Species Survival Commission Marine Turtles Specialist Group, Washington DC, 110-114.

[21] Teas, W. (1993) Species Composition and Size Class Distribution of Marine Turtle Strandings on the Gulf of Mexico and Southeast United States Coasts, 1985-1991. NOAA Technical Memorandum NMFS-SEFSC-315, 43 p.

[22] Balazs, G.H. (1999) Factors to Consider in the Tagging of Sea Turtles. In: Eckert, K.L., Bjorndal, K.A., Abreu-Grobois, F.A. and Donnelly, M., Eds., Research and Management Techniques for the Conservation of Sea Turtles, IUCN/Species Survival Commission Marine Turtles Specialist Group, Washington DC.

[23] Godley, B.J., Broderick, A.C. and Hays, G.H. (2001) Nesting of Green Turtles (Chelonia mydas) at Ascension Island, South Atlantic. Biological Conservation, 97, 151158.

[24] Miller, J.D. (1999) Determining Clutch Size and Hatching Success. In: Eckert, K.L., Bjorndal, K.A., Abreu-Grobois, F.A. and Donnelly, M., Eds., Research and Management Techniques for the Conservation of Sea Turtles, IUCN/Species Survival Commission Marine Turtle Specialist Group, Washington DC, 124-129.

[25] Bourjea, J., Nel, R., Jiddawi, N.S., Koonjul, M.S. and Bianchi, G. (2008) Sea Turtle Bycatch in the West Indian Oceans: Review, Recommendations and Research Priorities. Western Indian Ocean Journal of Marine Science, 7, 137-150.

[26] Putman, N.F., Abreu-Grobois, F.A., Broderick, A.C., Ciofi, C., Formia, A., Godley, B.J., Stroud, S., Pelembe, T., Verley, P. and Williams, N. (2014) Numerical Dispersal Simulations and Genetics Help Explain the Origin of Hawksbill Sea Turtles in Ascension Island. Journal of Experimental Marine Biology and Ecology, 450, 98-108.

[27] Snover, M.L., Balazs, G.H., Murakawa, S.K.K., Hargrove, S.K., Rice, M.R. and Seitz, W.A. (2013) Age and Growth Rates of Hawaiian Hawksbill Turtles (Eretmochelys imbricata) Using Skeletochronology. Marine Biology, 160, 37-46. https://doi.org/10.1007/s00227-012-2058-7

[28] Phillips, K.P., Mortimer, J.A., Jolliffe, K.G., Jorgensen, T.H. and Richardson, D.S. (2014) Molecular Techniques Reveal Cryptic Life History and Demographic Processes of a Critically Endangered Marine Turtle. Journal of Experimental Marine Biology and Ecology, 455, 29-37.

[29] McCann, P. (2010) Progress and Development of a Hawksbill Turtle (Eretmochelys imbricata) Monitoring Project, Seychelles: 2004-2008. Indian Ocean Turtle Newsletter, 11, 36-44.

[30] Antworth, R.L., Pike, D.A. and Stiner, J.C. (2006) Nesting Ecology, Current Status, and Conservation of Sea Turtles on an Uninhabited Beach in Florida, USA. Biological Conservation, 130, 10-15.

[31] Lindborg, R., Neidhardt, E., Witherington, B., Smith, J.R. and Savage, A. (2016) 
Factors Influencing Loggerhead (Caretta caretta) and Green Turtle (Chelonia mydas) Reproductive Success on a Mixed Use Beach in Florida. Chelonian Conservation and Biology, 15, 238-248. https://doi.org/10.2744/CCB-1206.1

[32] Fuentes, M.M.P.B., Hamann, M. and Limpus, C.J. (2010) Past, Current and Future Thermal Profiles of Green Turtle Nesting Grounds: Implications from Climate Change. Journal of Experimental Marine Biology and Ecology, 383, 56-64.

[33] Godfrey, M.H., D’Amato, A.F., Marcovaldi, M.Â. and Mrosovsky, N. (1999) Pivotal Temperature and Predicted Sex Ratios for Hatchling Hawksbill Turtles from Brazil. Canadian Journal of Zoology, 77, 1465-1473. https://doi.org/10.1139/z99-117

[34] Santos, C., Anastácio, R., Lopes, C., Ferrão, J., Souto, L. and Pereira M. Phylogeography of Hawksbill Turtle (Eretmochelys imbricata) in the North of Mozambique Channel (GenBank, unpub.).

[35] Wang, J.H., Fisler, S. and Swimmer, Y. (2010) Developing Visual Deterrents to Reduce Sea Turtle Bycatch in Gill Net Fisheries. Marine Ecology Progress Series, 408, 241-250. https://doi.org/10.3354/meps08577

[36] Gaines, S.D., White, C., Carr, M.H. and Palumbi, S.R. (2010) Designing Marine Reserve Networks for Both Conservation and Fisheries Management. Proceedings of the National Academy of Sciences of the United States of America, 107, 1828618293. https://doi.org/10.1073/pnas.0906473107

\section{Submit or recommend next manuscript to SCIRP and we will provide best service for you:}

Accepting pre-submission inquiries through Email, Facebook, LinkedIn, Twitter, etc. A wide selection of journals (inclusive of 9 subjects, more than 200 journals)

Providing 24-hour high-quality service

User-friendly online submission system

Fair and swift peer-review system

Efficient typesetting and proofreading procedure

Display of the result of downloads and visits, as well as the number of cited articles

Maximum dissemination of your research work

Submit your manuscript at: http://papersubmission.scirp.org/

Or contact nr@scirp.org 